\title{
Arginine Deiminase of Mycoplasma hominis: Cytoplasmic and Membrane-associated Forms
}

\author{
By JUEY-SHIN L. LIN \\ Channing Laboratory, Department of Medicine, Harvard Medical School and Brigham and \\ Women's Hospital, Boston, Massachusetts 02115, USA
}

(Received 1 October 1985; revised 28 January 1986)

\begin{abstract}
Membrane and cytoplasmic fractions of Mycoplasma hominis inhibited the multiplication of this mycoplasma. Arginine deiminase (EC 3.5.3.6), isolated from both fractions, reproduced the inhibition. The purified cytoplasmic deiminase had a subunit $M_{\mathrm{r}}$ of 49000 , a specific activity of 53 units (mg protein) $)^{-1}$ and an $A_{280} / A_{260}$ ratio of 1.76. The membrane-associated enzyme had an identical $M_{\mathrm{r}}$ but lower values for specific activity [ 39 units (mg protein) ${ }^{-1}$ ] and the $A_{280} / A_{260}$ ratio (1.46). In experiments in vitro, recent clinical isolates of $M$. hominis produced less arginine deiminase, but grew faster than the laboratory reference strain PG 21. In addition, other growth inhibitory components associated with membrane preparations were detected in recent clinical isolates but were absent from strain PG 21 .
\end{abstract}

\section{INTRODUCTION}

In a previous study, cell surface antigens of Mycoplasma hominis were analysed by crossabsorption (Lin, 1980). Membrane preparations obtained from seven reference strains of this mycoplasma were used to absorb antisera prepared against whole cells; these preparations, at certain concentrations, consistently inhibited the growth of the homologous and heterologous strains of $\boldsymbol{M}$. hominis. The present paper reports a further investigation of this phenomenon and shows the presence of cytoplasmic and membrane-associated arginine deiminase (EC 3.5.3.6) which inhibit the multiplication of $M$. hominis.

\section{METHODS}

$M$. hominis strains and antisera. The reference strains for seven serotypes of $M$. hominis were strain PG 21 and six others, isolated and purified in this laboratory (Lin et al., 1975). Strain PG 21 had been used as the laboratory reference strain for $M$. hominis and the number of passages in vitro was not clear; three strains of PG 21 from different sources (ATCC 23114, NIH-Chanock, NIH-Baril) were used in the fourth passage from the stock strain received. All other strains were used in the fourth or the fifth passages after the initial isolation and purification and were considered as recent clinical isolates (fewer than 10 passages in vitro). Their initial isolates, stored at $-70^{\circ} \mathrm{C}$, were also available.

Strains were grown at $37^{\circ} \mathrm{C}$ in modified Hayflick's medium and were stored at $-70^{\circ} \mathrm{C}$. The titre of organisms was expressed as $50 \%$ colour change units $\left(\mathrm{CCU}_{50^{\circ}}\right)$ (Lin \& Kass, 1975). Antisera against whole cells for each strain of mycoplasma, and control sera from animals immunized with uninoculated Hayflick's medium, were prepared in rabbits as described by Lin et al. (1975). Antisera to two other arginine-utilizing species, $M$. salivarium and $M$. orale, were purchased from Microbiological Associates.

Measurements of growth. $M$. hominis strains were grown at $37^{\circ} \mathrm{C}$ in modified Edward's broth without deoxyribonucleate (Razin \& Rottem, 1976), supplemented with $4 \%(\mathrm{v} / \mathrm{v})$ horse serum, $12 \mathrm{mM}$-L-arginine and $0.002 \%(\mathrm{w} / \mathrm{v})$ phenol red; the $\mathrm{pH}$ was adjusted to 6.8 . Actively growing cells harvested in the early exponential phase in Hayflick's medium were inoculated into prewarmed Edward's broth at 1/1000 dilutions. Samples were harvested at the indicated times at $37^{\circ} \mathrm{C}$. The $\mathrm{pH}$ of the harvested culture was compared with a set of colour references made with a sterile, uninoculated broth; titres of the mycoplasmas were determined in Hayflick's medium. Protein was determined by the Lowry method using crystalline bovine serum albumin as a reference.

Abbreriations: CCU, colour change units; GI, growth inhibition. 
Arginine deiminase activity was assayed by the method of Archibald as modified by Ratner (1955); one unit of enzyme activity was defined as the formation of $1 \mu \mathrm{mol}$ citrulline $\mathrm{min}^{-1}$ at $37^{\circ} \mathrm{C}$. Whole cells were disrupted by freeze-thawing five times before the determination.

Preparations of cytoplasmic and membrane fractions. Overnight cultures in Edward's broth (pH 7.0-7.2) were harvested by centrifuging at $10000 \mathrm{~g}$ for $30 \mathrm{~min}$. They were then washed twice at $5^{\circ} \mathrm{C}$ with sterile $0 \cdot 25 \mathrm{M}-\mathrm{NaCl}$, suspended in $0.25 \mathrm{M}-\mathrm{NaCl}$, concentrated to $1 / 100$ the volume of the original culture, and disrupted by sonication as described by Weickman \& Fahrney (1977). Concentrated cell preparations were streaked on blood agar plates which were incubated at $37^{\circ} \mathrm{C}$ to detect bacterial contamination. Membranes were collected by centrifuging at $45000 \mathrm{~g}$ for $45 \mathrm{~min}$. They were then washed consecutively with deionized water, $0.05 \mathrm{M}-\mathrm{NaCl}$ in $0.01 \mathrm{M}$-phosphatebuffered saline (PBS), pH 7.2, and deionized water (Razin \& Rottem, 1976). The original supernatants, further centrifuged at $180000 \mathrm{~g}$ for $1 \mathrm{~h}$, were considered as cytoplasmic fractions. They were concentrated with an Amicon concentrator (B15) to $10 \mathrm{mg}$ protein $\mathrm{ml}^{-1}$, if necessary. Both preparations were stored at $-70^{\circ} \mathrm{C}$.

Purification of arginine deiminase. The enzymes were isolated from cytoplasmic fractions $\left(10 \mathrm{mg}\right.$ protein $\left.\mathrm{ml}^{-1}\right)$ by protamine sulphate fractionation $\left(1 \mathrm{mg} \mathrm{ml}^{-1}\right.$; Weickman \& Fahrney, 1977). Supernatant from the fractionation (2-3 ml) was applied directly to an Ultrogel column $(1.6 \times 87 \mathrm{~cm}$, AcA 44, LKB), and was eluted with 0.01 M-PBS, pH 7.2 (flow rate $2-3 \mathrm{ml} \mathrm{h}^{-1}$ ). $A_{280}$ and precipitin reactions to antiserum PG21 (immunodiffusion plate, pattern B, Hyland) and determined for each $2 \mathrm{ml}$ fraction. Protein and arginine deiminase activity were determined from $A_{280}$ peak fractions and/or those showing precipitin reactions.

Active fractions were combined, concentrated with Amicon B15 concentrators to 1-2 ml, rechromatographed on the same column and eluted with $0.025 \mathrm{M}$-Tris/ $\mathrm{HCl}$ buffer, $\mathrm{pH} 9 \cdot 0$. If the specific activities of the enzyme fractions were more than 50 units (mg protein) ${ }^{-1}$, they were considered to be pure (Weickmann et al., 1978) and were stored at $-70^{\circ} \mathrm{C}$.

To extract enzymes from membrane preparations, Tween 20 was added to the preparations (4-5 mg protein $\mathrm{ml}^{-1}$ ) in $0.02 \mathrm{M}$-Tris/ $\mathrm{HCl}$ buffer, $\mathrm{pH} 9.0$; the preparations were then shaken at room temperature for $2 \mathrm{~h}$ and centrifuged at $180000 \mathrm{~g}$ for $2 \mathrm{~h}$ (Johansson et al., 1975). The supernatant (1 ml) was then chromatographed, firstly on an Ultrogel AcA 34 column $(1 \times 53 \mathrm{~cm})$ with PBS $(\mathrm{pH} \mathrm{7.2)}$ to remove the detergent, and then on an Ultrogel AcA 44 column with $\mathrm{Tris} / \mathrm{HCl}$ buffer, $\mathrm{pH} 9 \cdot 0$, to purify enzymes.

Homogeneity of the purified enzymes was ascertained by immunoelectrophoresis and gel electrophoresis. Disc polyacrylamide gel electrophoresis was done in the presence of $1 \% \operatorname{SDS}$ (Fairbanks et al., 1971). The $M_{\mathrm{r}}$ of purified enzymes was estimated with a reference kit (Pharmacia), which contained the following standards: thyroglobulin $\left(M_{\mathrm{r}} 669000\right)$, ferritin (440000), catalase (232000), lactate dehydrogenase (140000) and albumin (67000). Immunoelectrophoresis (LKB kit) was done with the purified enzyme against the homologous and heterologous antisera prepared against whole cells.

Growth inhibition. Twofold serial dilutions of material with deiminase activity $(0.05 \mathrm{ml})$ were made in Hayflick's medium in the microtitre system (Falcon) and, unless otherwise stated, $10-100 \mathrm{CCU}_{50 \%}$ of the mycoplasmas in $0.15 \mathrm{ml}$ of the medium were added to each well. Plates were sealed and incubated at $37^{\circ} \mathrm{C}$. The highest dilution which prevented the $\mathrm{pH}$ changes of the medium after $5 \mathrm{~d}$ was considered as containing 1 growth inhibition (GI) unit (Lin \& Kass, 1975).

\section{RESULTS}

\section{Growth and production of arginine deiminase}

In modified Edward's medium, there were differences in growth and enzyme production between strain PG 21 and the other six strains, as represented by strain 93 (Table 1). Early exponential phase growth was reached at $\mathrm{pH} 7 \cdot 0-7 \cdot 2$, and it took more than $24 \mathrm{~h}$ for strain PG 21 to reach that phase compared to $\leqslant 20 \mathrm{~h}$ for strain 93 . Strain PG 21 produced $2-5$ times more enzyme with a constant rate of production. On the other hand, the rate of enzyme production for strain 93 increased gradually from early to late exponential phase as reflected in increasing specific activities.

Approximately $45 \%$ of the cellular proteins and $95 \%$ of the deiminase activity were recovered in the cytoplasmic fraction. Although membrane preparations consistently showed low deiminase activity (Table 1), there were again differences between strains PG 21 and 93. Membrane preparations from strain PG 21 had 2-3 times more deiminase activity, but lower GI activity, than those from strain 93 . When the GI activities were compared with the deiminase activities, it was found that strain PG 21 had 30-50 GI units (deiminase unit) ${ }^{-1}$ whereas strain 93 had 300-500 GI units (deiminase unit) ${ }^{-1}$. No such differences were observed for cytoplasmic fractions (Table 2). As shown below, purified membrane enzymes from both strains had the 
Table 1. Growth and production of arginine deiminase in M. hominis

$M$. hominis strains were grown in modified Edward's broth and incubated at $37^{\circ} \mathrm{C}$. At the indicated times, samples were harvested and activities were determined: titre $=50 \%$ colour change unit $\left(\mathrm{CCU}_{50}\right) \mathrm{ml}^{-1}$; protein $=\mathrm{mg} \mathrm{l}^{-1}$; enzyme $=$ deiminase units $(\mathrm{mg} \text { cell protein })^{-1}$. Strain PG 21 is the original laboratory reference strain and strain 93 , representative of the other six reference strains, is a recent clinical isolate.

\begin{tabular}{|c|c|c|c|c|c|c|c|c|c|c|}
\hline \multirow{3}{*}{$\begin{array}{l}\text { Time of } \\
\text { incubation } \\
\text { (h) }\end{array}$} & & & & & & & \multicolumn{4}{|c|}{ Enzyme } \\
\hline & \multicolumn{2}{|c|}{$\mathrm{pH}$} & \multicolumn{2}{|c|}{ Titre } & \multicolumn{2}{|c|}{ Protein } & \multicolumn{2}{|c|}{ Cell } & \multicolumn{2}{|c|}{ Membrane } \\
\hline & PG 21 & $93^{\prime}$ & PG 21 & 93 & PG 21 & 93 & PG 21 & 93 & PG 21 & 93 \\
\hline 0 & \multicolumn{2}{|c|}{6.8} & $10^{4 \cdot 8}$ & $10^{4 \cdot 0}$ & & & & & & \\
\hline 16 & 6.8 & 7.0 & $10^{7.0}$ & $10^{7.8}$ & $2 \cdot 0$ & 10.0 & $5 \cdot 27$ & 0.87 & & 0.08 \\
\hline 20 & 6.8 & 7.2 & $10^{7.3}$ & $10^{8.8}$ & 4.9 & $47 \cdot 4$ & 5.03 & $1 \cdot 11$ & 0.2 & 0.12 \\
\hline 24 & 7.0 & 7.4 & $10^{7.8}$ & $10^{8.5}$ & $25 \cdot 3$ & 92.0 & $5 \cdot 10$ & 1.87 & 0.45 & 0.22 \\
\hline 26 & $7 \cdot 2$ & 7.6 & $10^{8 \cdot 3}$ & $10^{8.5}$ & 47.5 & 91.0 & 5.07 & 1.87 & 0.65 & 0.28 \\
\hline 30 & $7 \cdot 3$ & 7.8 & $10^{8 \cdot 0}$ & $10^{7.8}$ & 52.2 & 64.5 & 5.03 & 2.76 & 0.63 & 0.27 \\
\hline 34 & $7 \cdot 5$ & $8 \cdot 1$ & $10^{8 \cdot 0}$ & $10^{6 \cdot 8}$ & $85 \cdot 3$ & $33 \cdot 3$ & 5.87 & 2.54 & 0.78 & 0.24 \\
\hline $16-24^{*}$ & \multicolumn{2}{|c|}{$7 \cdot 0-7 \cdot 2$} & $10^{8 \cdot 0}$ & $10^{8.5}$ & $\begin{array}{c}35.9 \pm \\
1.8\end{array}$ & $\underset{41.6}{41.5 \pm}$ & $\begin{array}{l}5.05 \pm \\
0.04\end{array}$ & $\begin{array}{l}1.55 \pm \\
0.29\end{array}$ & $\begin{array}{l}0.49 \pm \\
0.1\end{array}$ & $\begin{array}{l}0.16 \pm \\
0.06\end{array}$ \\
\hline
\end{tabular}

* Combined data for three strains of PG 21 and six reference strains of $M$. hominis; mean \pm SD.

Table 2. Growth inhibiting activities of membrane and cytoplasmic fractions of $M$. hominis

Mycoplasmas ( $10-100 \mathrm{CCU}_{50}$ ) were grown in Hayflick's medium with twofold serial dilutions of test material. The highest dilution which prevented the $\mathrm{pH}$ changes of the medium after $5 \mathrm{~d}$ incubation at $37^{\circ} \mathrm{C}$ was considered as containing $1 \mathrm{GI}$ unit.

$\begin{array}{lcc}\text { Strain } & \overbrace{\text { Membrane }} & \begin{array}{c}\text { GI units } \\ \left.\text { Cytoplasm }^{\text {(deiminase unit) }}\right)^{-1}\end{array} \\ \text { PG 21* } & 41 \pm 6 & 40 \pm 7 \\ 93^{*} & 382 \pm 41 & 49 \pm 8 \\ 93 \text { (Original isolate) } & 336 & 29 \\ \text { Other six strains } & 278 \pm 60 & 33 \pm 8\end{array}$

* Results of 4 different preparations; mean \pm SD.

same values for GI units (deiminase unit) ${ }^{-1}$, indicating the presence of additional growthinhibitory components in strain 93.

Initial isolates of two reference strains $\left(93\right.$ and 132) stored at $-70^{\circ} \mathrm{C}$ were recovered and tested. When cells were harvested in exponential phase ( $\mathrm{pH} 7 \cdot 0-7 \cdot 2)$, the patterns of production of arginine deiminase and GI activities in the membrane and cytoplasmic fractions were similar to those of the recent clinical isolates, within the ranges indicated above (Tables 1 and 2).

\section{Cytoplasmic enzyme}

Purification of arginine deiminase from the cytoplasmic fraction of strains PG 21 and 93 is summarized in Fig. 1 and Table 3. The specific activities of the purified enzymes were 55 and 51 units (mg protein $)^{-1}$ respectively, representing 5- to 13 -fold increases in the activity. It should be noted that the values for GI units (deiminase unit) ${ }^{-1}$ of the preparations remained almost constant, between 32 and 42, after each step of the purification procedure.

Purified enzymes showed (1) one major polypeptide band in polyacrylamide gel electrophoresis, with a subunit $M_{\mathrm{r}}$ of $49000\left(R_{F} 0.61 \pm 0.01\right)$ Fig. $2 ;(2)$ one precipitin line in immunoelectrophoresis and immunodiffusion against the homologous and heterologous antisera prepared against whole cells; (3) growth inhibition towards the homologous and heterologous 


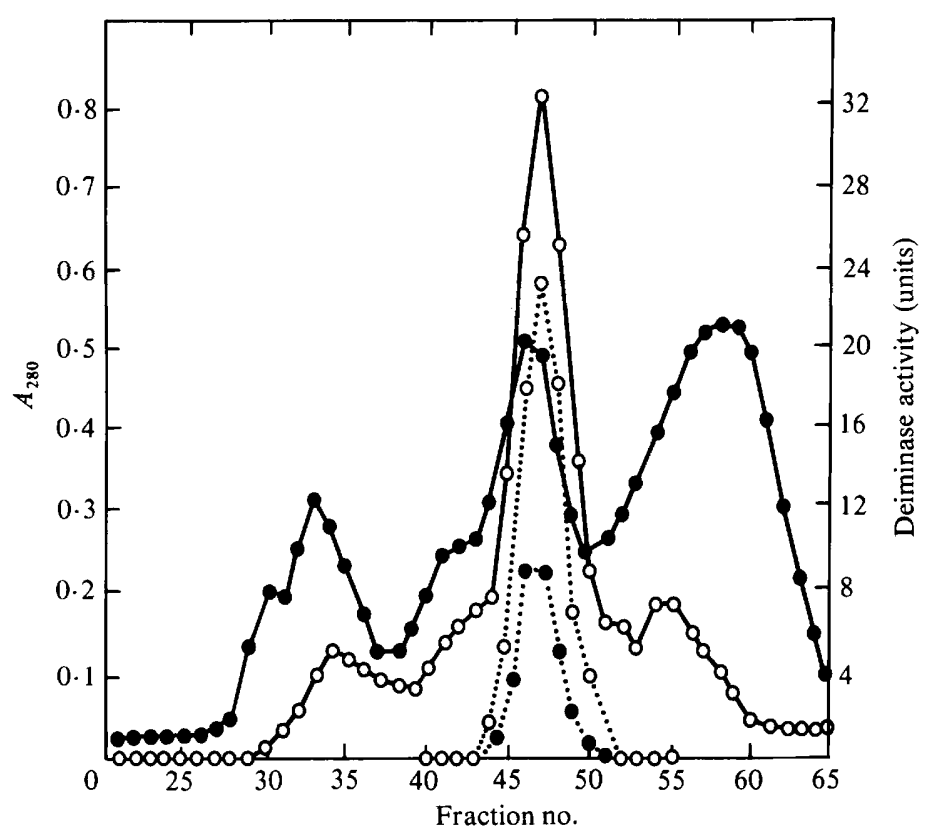

Fig. 1. Isolation of arginine deiminase by Ultrogel AcA 44 chromatography. Cytoplasmic fractions (2$3 \mathrm{ml}$ ), obtained after protamine sulphate precipitation, and containing approximately 200 and 80 units of enzyme from strains PG $21(O)$ and $93(O)$ respectively, were loaded on the column $(1.6 \times 87 \mathrm{~cm})$ and eluted with $0.01 \mathrm{M}$-PBS, $\mathrm{pH} 7.2$ (flow rate $2 \mathrm{ml} \mathrm{h}^{-1}$; fraction vol. $2 \mathrm{ml}$ ). -,$A_{280} ; \cdots \cdots$, arginine deiminase activity.

Table 3. Purification of cytoplasmic deiminase from $M$. hominis

Cytoplasmic fractions $\left(10 \mathrm{mg}\right.$ protein $\left.\mathrm{ml}^{-1}\right)$ were extracted with protamine sulphate and chromatographed on Ultrogel AcA 44 columns with $0.01 \mathrm{M}-\mathrm{PBS}, \mathrm{pH} 7 \cdot 2$. Active fractions were rechromatographed with $0.015 \mathrm{M}$-Tris/ $\mathrm{HCl}$ buffer, $\mathrm{pH} 9.0$.

\begin{tabular}{|c|c|c|c|c|c|}
\hline Strain & Step & $\begin{array}{l}\text { Protein } \\
\text { (mg) }\end{array}$ & $\begin{array}{c}\text { Specific activity } \\
\text { [units (mg protein })^{-1} \text { ] }\end{array}$ & $\begin{array}{l}\text { Total activity } \\
\quad \text { (units) }\end{array}$ & $\begin{array}{l}\text { Yield } \\
(\%)\end{array}$ \\
\hline PG 21 & $\begin{array}{l}\text { Extract } \\
\text { Chromatography } \\
\text { Rechromatography }\end{array}$ & $\begin{array}{r}18 \cdot 0 \\
5 \cdot 6 \\
1 \cdot 4\end{array}$ & $\begin{array}{l}11 \cdot 2 \\
33 \cdot 5 \\
55 \cdot 0\end{array}$ & $\begin{array}{r}201 \cdot 6 \\
187 \cdot 6 \\
77 \cdot 0\end{array}$ & $\begin{array}{l}100 \\
93 \cdot 1 \\
38 \cdot 2\end{array}$ \\
\hline 93 & $\begin{array}{l}\text { Extract } \\
\text { Chromatography } \\
\text { Rechromatography }\end{array}$ & $\begin{array}{l}21 \\
4 \cdot 8 \\
0 \cdot 7\end{array}$ & $\begin{array}{r}3 \cdot 9 \\
16 \cdot 5 \\
50 \cdot 8\end{array}$ & $\begin{array}{l}81 \cdot 9 \\
79 \cdot 2 \\
35 \cdot 6\end{array}$ & $\begin{array}{l}100 \\
96 \cdot 7 \\
43 \cdot 5\end{array}$ \\
\hline
\end{tabular}

strains; (4) $A_{280} / A_{260}$ ratios of 1.74 and $1 \cdot 78$. Among the seven reference antisera, immunoprecipitation was strongest for strain PG 21 . The other six reference antisera, and antisera to $M$. salivarium and $M$. orale, showed weak reactions. Control antisera showed no activity.

\section{Membrane-associated deiminase}

When washed membranes were extracted with Tween 20 , all the deiminase activity was recovered in the Tween 20 fractions. Approximately $45 \%$ and $25 \%$ of the membrane proteins were solubilized from strains PG 21 and 93 respectively. Deiminase purified from membranes of strains PG 21 and 93 had an $R_{F}$ of $0 \cdot 6$ (Fig. 2), $37 \cdot 7$ and $40 \cdot 1$ deiminase units (mg protein) ${ }^{-1}, 35 \cdot 1$ and $30.8 \mathrm{GI}$ units (deiminase unit) ${ }^{-1}$, and $A_{280} / A_{260}$ ratios of 1.40 and 1.52 , respectively.

Because of the low deiminase content of membrane preparations, active fractions were much 
A

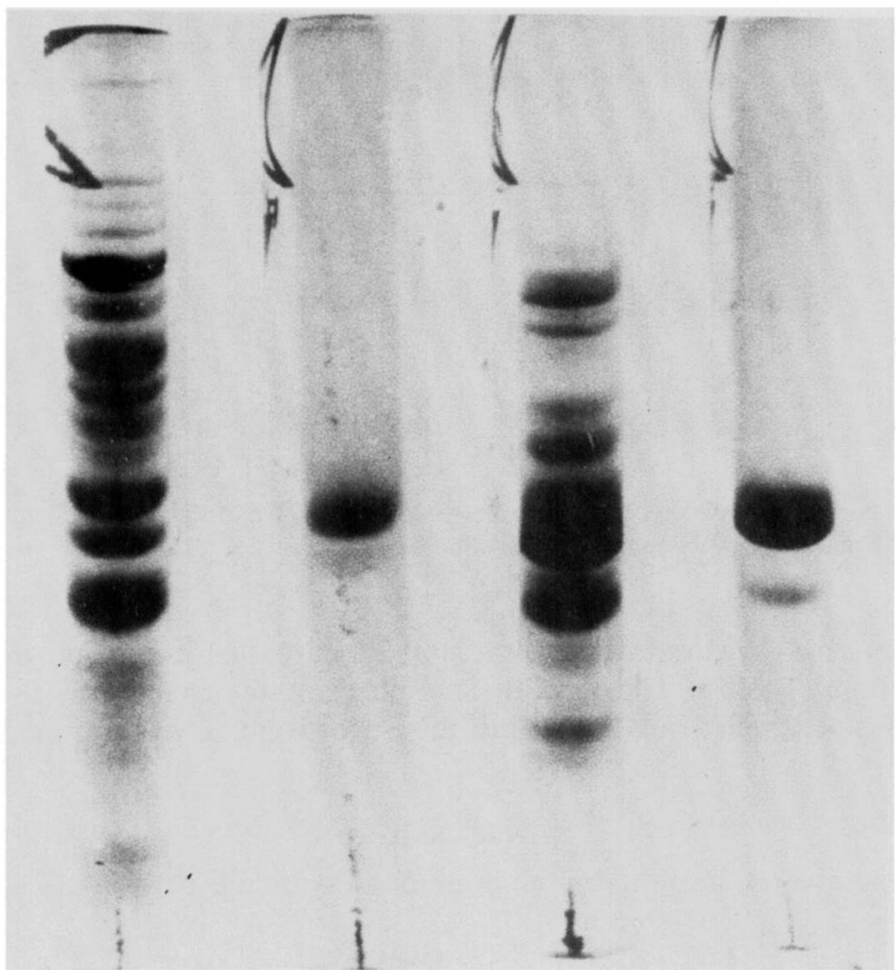

Fig. 2. SDS-polyacrylamide disc gel electrophoresis of preparations from $M$. hominis strain PG 21. A, Membrane preparations $(110 \mu \mathrm{g}$ proteins); $\mathrm{B}$, membrane arginine deiminase $(10 \mu \mathrm{g})$; $\mathrm{C}$, cytoplasmic preparations $(150 \mu \mathrm{g}) ; \mathrm{D}$, cytoplasmic arginine deiminase $(30 \mu \mathrm{g})$.

Table 4. Growth inhibiting capacity of arginine deiminase in relation to $M$. hominis cell number

Twofold serial dilutions of purified arginine deiminase from strain PG 21 were incubated with 10-fold serial dilutions of cells from strain PG 21 in microtitre plates. The highest dilutions of enzyme which inhibited the growth of the mycoplasma were recorded. Preparation A contained 3.8 deiminase units, and $B \quad 7 \cdot 1$ deiminase units.

\begin{tabular}{|c|c|c|c|c|}
\hline \multirow{2}{*}{$\begin{array}{c}\text { Cell titre } \\
\left(\mathrm{CCU}_{50 \%} \mathrm{ml}^{-1}\right)\end{array}$} & \multicolumn{2}{|c|}{$\begin{array}{c}\text { GI units } \\
\text { (deiminase } \\
\text { unit) })^{-1}\end{array}$} & \multicolumn{2}{|c|}{$\begin{array}{l}\text { GI units } \\
\text { (deiminase } \\
\text { unit) }^{-1}\end{array}$} \\
\hline & A & B & A & B \\
\hline $10^{8 \cdot 3}-10^{7 \cdot 3}$ & $2 \cdot 1$ & $2 \cdot 3$ & 0.48 & 0.44 \\
\hline $10^{6 \cdot 3}-10^{5 \cdot 3}$ & $4 \cdot 2$ & $9 \cdot 1$ & 0.24 & 0.11 \\
\hline $10^{4 \cdot 3}-10^{3 \cdot 3}$ & 8.4 & $16 \cdot 6$ & $0 \cdot 12$ & 0.06 \\
\hline $10^{2 \cdot 3}-10^{1 \cdot 3}$ & $16 \cdot 8$ & $35 \cdot 2$ & 0.06 & 0.03 \\
\hline
\end{tabular}

more difficult to identify by using $A_{280}$; they were identified by the precipitin reaction and/or by GI. Protein and deiminase activity were often determined after active fractions were concentrated 5-10 times. From $60-75 \mathrm{mg}$ of membrane proteins, approximately 0.2 and $0.1 \mathrm{mg}$ enzyme were purified from strains PG 21 and 93 , respectively ( $38 \%$ and $28 \%$ recovery).

\section{Growth inhibition}

GI values of purified enzyme preparations were inversely related to the concentrations of mycoplasmal cells being tested; 0.5 units of deiminase inhibited $\leqslant 10^{8.3} \mathrm{CCU}_{50 \%}$ of the mycoplasma (Table 4). Both crude and purified enzyme preparations from strains PG 21 and 93 inhibited cultures of strains PG 21 and 93 at 0.5 units deiminase $\mathrm{ml}^{-1}$; the mycoplasma 
Table 5. Growth inhibition of $M$. hominis by crude cytoplasmic and membrane preparations

Strain PG 21 in Hayflick's medium was incubated with homologous preparations at $37^{\circ} \mathrm{C}$. Arginine deiminase activity in the reaction mixtures was 0.5 units $\mathrm{ml}^{-1}$.

\begin{tabular}{|c|c|c|c|}
\hline \multirow{2}{*}{$\begin{array}{c}\text { Time at } \\
37^{\circ} \mathrm{C} \\
\text { (h) }\end{array}$} & \multirow[b]{2}{*}{ Control } & \multicolumn{2}{|c|}{$\begin{array}{l}\text { Mycoplasma titres } \\
\left(\mathrm{CCU}_{50 \%} \mathrm{ml}^{-1}\right)\end{array}$} \\
\hline & & $\begin{array}{c}\text { Cytoplasmic } \\
\text { fraction }\end{array}$ & $\begin{array}{l}+ \text { Membrane } \\
\text { fraction }\end{array}$ \\
\hline 0 & $10^{6 \cdot 1}$ & & \\
\hline 4 & $10^{6 ! 4}$ & & \\
\hline 24 & $10^{8 \cdot 8}$ & $10^{5 \cdot 8}$ & $10^{6 \cdot 1}$ \\
\hline 30 & $10^{8 \cdot 5}$ & $10^{4 \cdot 8}$ & $10^{5 \cdot 6}$ \\
\hline 48 & $10^{7 \cdot 3}$ & $10^{3 \cdot 6}$ & $10^{3 \cdot 1}$ \\
\hline 72 & $10^{3 \cdot 1}(>8.0) \dagger$ & $10^{1.8}(7 \cdot 2) \dagger$ & $10^{2 \cdot 6}(7.0) \dagger$ \\
\hline
\end{tabular}

* Purified cytoplasmic deiminase from strain PG 21 had the same effect.

$\dagger$ Final culture $\mathrm{pH}$ shown in parentheses.

remained viable in the growth medium for at least $2 \mathrm{~d}$ but failed to multiply in the presence of enzyme preparations (Table 5). The $\mathrm{pH}$ of the inhibited culture remained low $(<8.0)$, suggesting that arginine was not depleted but that the metabolism of arginine was inhibited in the medium.

\section{DISCUSSION}

Prokaryotes metabolize arginine by the arginine dihydrolase pathway (Razin, 1978);

$$
\begin{aligned}
& \text { Arginine }+\mathrm{H}_{2} \mathrm{O} \stackrel{\begin{array}{c}
\text { Arginine } \\
\text { deiminase }
\end{array}}{\longrightarrow} \text { citrulline }+\mathrm{NH}_{3} \\
& \text { Ornithine } \\
& \text { transcarbamylase } \\
& \text { Citrulline }+\mathbf{P}_{\mathrm{i}} \stackrel{\text { transcarbamylase }}{=} \text { ornithine }+ \text { carbamyl phosphate } \\
& \text { Carbamyl phosphate }+\mathrm{ADP} \stackrel{\begin{array}{c}
\text { Carbamate } \\
\text { kinase }
\end{array}}{\rightleftharpoons} \mathrm{ATP}+\mathrm{CO}_{2}+\mathrm{NH}_{3}
\end{aligned}
$$

Arginine-utilizing strains of mycoplasmas are particularly toxic to mammalian cells in culture. Soluble extracts of these mycoplasmas inhibit lymphocyte mitosis, antibody production and the multiplication of mammalian cells in culture; partially purified arginine deiminases from mycoplasmas, bacteria and yeasts reproduce these effects (Simberkoff et al., 1969; Gill \& Pan, 1970). Large amounts of the arginine dihydrolase pathway enzymes were present in a laboratory reference strain of murine mycoplasma, $M$. arthritidis, grown in an artificial medium, and arginine deiminase constitutes about $10 \%$ of the cytoplasmic proteins (Schimke et al., 1966; Weickmann et al., 1978). The results reported here for the laboratory reference strain PG 21 of the human genital mycoplasma, $M$. hominis, are similar. In addition, membrane-associated arginine deiminase has been detected and isolated from this strain. However, recent or original clinical isolates of $M$. hominis have been shown to contain less of the enzymes than the laboratory reference strain.

The presence of cytoplasmic and membrane-associated arginine deiminases in $M$. hominis suggests multiple metabolic roles for arginine in the non-glycolytic, arginine-utilizing mycoplasmas. It has been suggested that the arginine dihydrolase pathway is a major source of energy, but recent results suggest that arginine is used in $M$. hominis as an alternative energy source (Fenske \& Kenny, 1976). On the other hand, the pathway might be required for active 
transport of amino acids (Razin et al., 1968), a possibility supported by the presence of membrane-associated arginine deiminase. Presumably, the other two enzymes in the dihydrolase pathway would be expected to be present in membranes of $M$. hominis.

Two distinct forms of arginine deiminase have been identified in the cytoplasm of $M$. arthritidis; deiminase $\mathrm{I}$ is found only in exponential phase cultures and deiminase II accounts for $30-60 \%$ of the enzyme from late exponential phase cultures (Weickmann et al., 1978). The two forms have identical subunit sizes $\left(M_{\mathrm{r}} 49000\right)$ but deiminase II has lower values for specific activity [55 and 44 units (mg protein) ${ }^{-1}$ and for the $A_{280} / A_{260}$ ratio (1.5 compared to $1 \cdot 8$ ). The results presented here show that the cytoplasmic arginine deiminase from $M$. hominis resembles deiminase $I$ in physical properties and that the membrane-associated enzyme resembles deiminase II. The membrane-associated deiminase appears to be a peripheral protein since it can be extracted by Tween 20 . Unfortunately, Weickmann et al. (1978) did not determine deiminase activity in the membrane, so more direct comparison with the present work to determine the intracellular localization of deiminase II is not possible.

In the experimental conditions reported here, the minimum amount of mycoplasma arginine deiminase required to inhibit the multiplication of $M$. hominis was 0.03-0.06 units ml-1 (Table 4). These figures are comparable to the 0.02 units of Streptococcus enzymes required to inhibit lymphocyte mitosis, and the 0.05 units of $M$. orale enzymes and the 0.03 units of yeast enzymes required to inhibit cell division of a leukaemic cell line (Simberkoff et al., 1969; Gill \& Pan, 1970). Thus, it appears that cells requiring arginine for growth are susceptible to the inhibitory effects of arginine deiminases from various sources. The possibility exists that release of the enzyme in vivo may play a role in the pathogenesis of diseases caused by $M$. hominis. On the other hand, some potent growth-inhibiting components are associated with membranes of recent clinical isolates but absent from the laboratory reference strain PG 21. Further studies are needed to identify these components and to determine whether they play a role in pathogenesis.

Recent clinical isolates of $M$. hominis produced less arginine deiminase, in both membranes and cytoplasm, but grew faster than the laboratory reference strain PG 21 under the experimental conditions used. The finding of growth inhibitory components other than the deiminase in membranes of recent clinical isolates but not in strain PG 21, and previous results showing that strain PG 21, among the seven reference strains of $M$. hominis examined, had the fewest antigens expressed at the cell surface (Lin, 1980), indicate that recent clinical isolates of $M$. hominis are biochemically different from laboratory-adapted strains and that losses of 'virulence' factors may occur during laboratory passages.

Understanding the mechanism of growth inhibition may help to define the metabolic and pathogenic role of arginine deiminase. Preliminary results suggest that attachment of arginine deiminases to mycoplasma cells may inhibit the metabolism of arginine and, concurrently, multiplication of the mycoplasma, since live mycoplasma cells or membrane preparations in non-growth media absorbed deiminase and the corresponding growth inhibiting activities from the cytoplasmic fractions. It is also possible that reactive sites for deiminase and growth inhibition may be different. An antiserum to the purified cytoplasmic enzyme of strain PG 21 has been prepared; at a 1:4 dilution this antiserum neutralized $>90 \%$ of the cytoplasmic arginine deiminase (2 units) and growth inhibiting (128 GI units) activities of strain PG 21. It also neutralized $70 \%$ of the deiminase activity ( 1 unit) in membranes but failed to affect growth inhibiting activity (64 units). Further studies are needed to understand the mechanism of growth inhibition. Preparations of monoclonal antibodies to the enzyme may help to define the mechanisms involved in growth inhibition.

I thank Y. C. Tsai, M. I. Kendrick and J. Curran for their assistance.

\section{REFERENCES}

Fairbanks, G., Steck, T. L. \& Wallach, D. F. H. (1971). Electrophoretic analysis of the major polypeptides of the human erythrocyte membrane. Biochemistry 10, 2608-2616.
FENSKe, J. D. \& KenNey, G. E. (1976). Role of arginine deiminase in growth of Mycoplasma hominis. Journal of Bacteriology 126, 501-510.

Gill, P. \& PAN, J. (1970). Inhibition of cell division in 
L5178 Y cells by arginine-degrading mycoplasmas: the role of arginine deiminase. Canadian Journal of Microbiology 16, 415-419.

Johansson, D. E., Blomevist, I. \& Huerten, S. (1975). Purification of membrane proteins from Acholeplasma laidlawii by agarose suspension electrophoresis in Tween 20 and polyacrylamide and dextran gel electrophoresis in detergent-free media. Journal of Biological Chemistry 250, 2463-2469.

LIN, J.-S. L. (1980). An antigenic analysis for membranes of Mycoplasma hominis by cross-absorption. Journal of General Microbiology 116, 187-193.

LiN, J.-S. L. \& Kass, E. H. (1975). Complementdependent and complement-independent interactions between Mycoplasma hominis and antibodies in vitro. Journal of Medical Microbiology 8, 397-404.

Lin, J.-S. L., Alpert, S. \& Radnay, K. M. (1975). Combined type-specific antisera in the identification of Mycoplasma hominis. Journal of Infectious Diseases 131, 727-730.

RATNER, S. (1955). Enzymatic synthesis of arginine (condensing and splitting enzymes). Methods in Enzymology 2, 365-367.

Razin, S. (1978). The mycoplasmas. Microbiological Review's 42, 414-470.
Razin, S. \& RotTem, S. (1976). Techniques for manipulation of mycoplasma membrane. In Biochemical Analysis of Membranes, pp. 3-26. Edited by A. H. Muddy. London: Chapman \& Hall.

RazIN, S., GotTFried, L. \& RotTeM, S. (1968). Amino acid transport in mycoplasmas. Journal of Bacteriology 95, 1685-1691.

Schimke, R. T., Berlin, C. M., Sweeney, E. W. \& CARROLL, W. R. (1966). The generation of energy by the arginine dihydrolase pathway in Mycoplasma hominis 07. Journal of Biological Chemistry 241, 22282236.

Simberkoff, M. S., Thorbecke, F. J. \& Thomas, L. (1969). Studies of PPLO infection V. Inhibition of lymphocyte mitosis and antibody formation of mycoplasmal extracts. Journal of Experimental Medicine 129, 1163-1181.

WeickManN, J. L. \& FaHRNEy, D. E. (1977). Arginine deiminase from Mycoplasma arthritidis. Evidence for multiple forms. Journal of Biological Chemistry 252, 2615-2620.

Weickmann, J. L., Himmel, M. E., SQuire, G. E. \& FAHRNEY, D. E. (1978). Arginine deiminase from Mycoplasma arthritidis. Properties of the enzyme from log phase cultures. Journal of Biological Chemistry 253, 6010-6015. 